\title{
DEGENERATIVE DISC DISEASE IN YOUNG ADULTS: CYTOKINE PROFILE AND ANGIOGENIC FACTORS
}

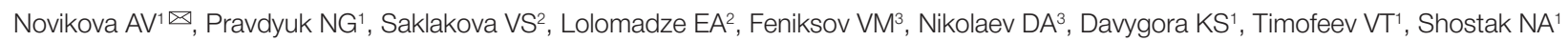

${ }^{1}$ Pirogov Russian National Research Medical University, Moscow, Russia

${ }^{2}$ Kulakov National Medical Research Center for Obstetrics, Gynecology and Perinatology, Moscow, Russia

${ }^{3}$ Pirogov City Clinical Hospital № 1, Moscow, Russia

Back pain (BP), associated with the degenerative disc disease (DDD), poses a heavy social and economic burden due to early disability and indications to surgery, emerging in young adults. Pathophysiological basis of premature intervertebral disc (IVD) degeneration is being actively studied. The study was aimed to define the profiles of inflammatory cytokines in DDD, as well as their relationship to the structural spine diseases. The molecular genetic analysis of the mRNA gene abundance in patients with BP and herniated IVD after discectomy and healthy individuals was performed by the quantitative polymerase chain reaction method. High expression of TNF $\alpha$, IL17 was revealed in the IVD tissues of the affected patients $(p<0.01)$; the levels of TNF $\alpha$ and IL1 $\beta$ correlated with the DDD severity $(r=0.301$ and 0.37 ; $p<0.05)$. Elevated expression of IL1 $\beta$, IL6 was found in peripheral white blood cells $(p<0.01)$; the levels of IL6 negatively correlated with Modic type 1 and 2 changes $(r=-0.31 ; p<0.05)$, and the levels of IL17 positively correlated with the IVD herniation in combination with erosions of the adjacent vertebral body endplates and Modic changes $(r=0.401 ; p<0.05)$. The expression of VEGF-A in the IVD tissues and white blood cells negatively correlated with the DDD grades $(r=-0.85$; $p<0.001)$, indicating reduced vascularization in the terminal phase of the disease. The findings on DDD demonstrate the contribution of the local low-immune inflammation, coupled with the intense disc vascularization at the earlier stages, and associated with the reactive inflammation in vertebral bodies. The results are prerequisites for developing the anti-inflammatory and reparative therapy based on the DDD grade and the presence of Modic changes in young adults with BP.

Keywords: back pain, degenerative disc disease, young age, discectomy, cytokine expression, mRNA TNF $\alpha$, IL1 $\beta$, IL6, IL17, VEGF-A, Modic-changes Acknowledgements: we would like to thank neurosurgeons of the Department of Neurosurgery, Nekrasova MA, Babenkova W, Isaeva AN, Smirnova VA, Glukhova DS, Gabechiya GV, Choriyeva DB, Kozheva AKh, for assistance in our research.

Author contribution: Novikova AV — literature analysis, clinical data acquisition and biomaterial collection, preanalytical phase of the study, data analysis and interpretation, preparation of figures and graphs; Pravdyuk NG — literature analysis, task definition, study design, data analysis and interpretation; Saklakova VS literature analysis, analytic phase of laboratory testing, definition and statistical analysis of mRNA abundance in biomaterial, scheduling; Lolomadze EA — analysis of laboratory work, analysis of mRNA abundance in biomaterial; Feniksov VM and Nikolaev DA — admission to clinical data acquisition, neurological examination of patients, discectomy, biomaterial collection; Davygora KS — literature analysis, analysis of laboratory work; Timofeev VT — study planning, preanalytical phase of the study, evaluation of the data obtained; Shostak NA — research management, study design, data interpretation, manuscript editing.

Compliance with ethical standards: the study was approved by the Ethics Committee of Pirogov Russian National Research Medical University (protocol № 181 dated January 28, 2019); the informed consent to blood testing and investigation of intervertebral disc was obtained from all participants.

$\triangle$ Correspondence should be addressed: Anna V. Novikova Ostrovitianova, 1, Moscow, 117997, Russia; annove2008@mail.ru

Received: 22.11.2021 Accepted: 06.12.2021 Published online: 19.12.2021

DOI: 10.24075/brsmu.2021.061

\section{ДЕГЕНЕРАТИВНАЯ БОЛЕЗНЬ ДИСКА У МОЛОДЫХ: ЦИТОКИНОВЫЙ ПРОФИЛЬ И ФАКТОРЫ АНГИОГЕНЕЗА}

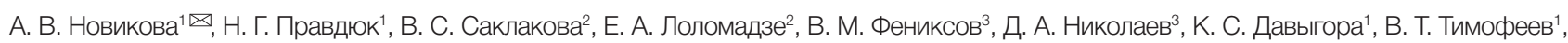

Н. А. Шостак ${ }^{1}$

${ }^{1}$ Российский национальный исследовательский медицинский университет имени Н. И. Пирогова, Москва, Россия

${ }^{2}$ Национальный медицинский исследовательский центр акушерства, гинекологии и перинатологии имени В. И. Кулакова, Москва, Россия

${ }^{3}$ Городская клиническая больница № 1 имени Н. И. Пирогова, Москва, Россия

Боль в спине (БС), ассоциированная с дегенеративной болезнью диска (ДБД), - тяжелое социальное и экономическое бремя вследствие ранней инвалидизации и возникновения показаний к оперативному вмешательству уже в молодом возрасте. Патофизиологические основы преждевременной дегенерации межпозвонкового диска (МПД) находятся на стадии активного изучения. Целью исследования было определить профиль воспалительных цитокинов при ДБД и их связь со структурными нарушениями в позвоночнике. У пациентов молодого возраста с БС и грыжей МПД, подвергшихся дискэктомии, и у здоровых лиц проводили молекулярно-генетический анализ представленности генов мРНК методом количественной полимеразной цепной реакции. У больных в ткани МПД выявлен высокий уровень экспрессии TNF $\alpha$, IL17 (p < 0,01); уровни TNF $\alpha$ и IL1 $\beta$ коррелировали с тяжестью ДБД ( $r=0,301$ и 0,37; p < 0,05). В лейкоцитах периферической крови обнаружена повышенная экспрессия IL1 $\beta$, IL6 ( $<<0,01$ ); yровень IL6 отрицательно коррелировал с I и II стадиями Modic-изменений ( $r=-0,31 ; p<0,05)$, IL17 прямо коррелировал с грыжей МПД в сочетании с эрозией замыкательных пластин и Modic ( $r=0,401 ; p<0,05)$. Экспрессия VEGF-A в ткани МПД и в лейкоцитах крови отрицательно коррелировала со стадией ДБД ( $r=-0,85$; p < 0,001), указывая на снижение активности васкуляризации в терминальной стадии. Данные, выявленные при ДБД, говорят о вкладе локального низкоиммунного воспаления, сопряженного с активной васкуляризацией диска на более ранних стадиях и ассоциированного с реактивным воспалением тел позвонков. Полученные результаты служат предпосылкой к разработке противовоспалительной и репаративной терапии в зависимости от стадии ДБД и наличия Modic-изменений у лиц молодого возраста с БС.

Ключевые слова: боль в спине, дегенеративная болезнь диска, молодой возраст, дискэктомия, экспрессия цитокинов, мPHK TNF $\alpha$, IL1ß, IL6, IL17, VEGF-A, Modic-изменения

Благодарности: врачам-нейрохирургам нейрохирургического отделения М. А. Некрасову, В. В. Бабенкову, А. Н. Исаеву, В. А. Смирнову, Д. С. Глухову, Г.В.Габечия, Д. Б. Чориеву, А. Х. Кожеву за помощь в исследовании.

Вклад авторов: А. В. Новикова - анализ литературы, сбор клинических данных и набор биоматериала, выполнение преаналитического этапа работы, анализ и интерпретация данных, подготовка рисунков и графиков; Н. Г. Правдюк - анализ литературы, постановка задачи, разработка дизайна исследования, анализ и интерпретация данных; В. С. Саклакова - анализ литературы, выполнение аналитической части лабораторной работы, определение и статистический анализ уровня представленности мРНК в биоматериале, составление графиков; Е. А. Лоломадзе - анализ лабораторной работы, анализ уровня представленности мРНК в биоматериале; В. М. Фениксов и Д. А. Николаев - допуск к набору клинического материала, неврологический осмотр пациентов, дискэктомия, получение биоматериала; К. С. Давыгора - анализ литературы, анализ лабораторной работы; В. Т. Тимофеев - планирование исследования, выполнение преаналитического этапа работы, оценка полученных данных; Н. А. Шостак руководство проведением исследования, разработка дизайна исследования, интерпретация данных, редактирование рукописи.

Соблюдение этических стандартов: исследование одобрено этическим комитетом РНИМУ им. Н. И. Пирогова (протокол № 181 от 28 января 2019 г.); от всех участников получено информированное согласие на проведение исследования образцов крови и межпозвонкового диска.

$\bowtie$ Для корреспонденции: Анна Владимировна Новикова ул. Островитянова, д. 1, г. Москва, 117997, Россия; annove2008@mail.ru Статья получена: 22.11.2021 Статья принята к печати: 06.12.2021 Опубликована онлайн: 19.12.2021 DOI: $10.24075 /$ vrgmu.2021.061 
Back pain (BP) is one of the main causes of the patients' disability in the developed world, resulting in permanent disability. BP is found in all age groups. Thus, according to a Polish study, BP recurrence within 34 years was observed in $85 \%$ of males and $86 \%$ of females with the BP onset at the age of 14 [1]. Degenerative disc disease (DDD), resulting from degradation and inflammation of the intervertebral disc (IVD) tissues, is one of the BP variants, associated with unfavourable outcomes [2]. DDD is a chronic condition with a trend towards progression. Despite the fact that there are still no explicit criteria for distinguishing between the "natural" physiological disc ageing and the pathological degeneration, also found in young adults, the term "DDD" is used by both clinicians and pathologists to define the disc extracellular matrix disruption with impaired homeostasis and the inflammatory process induction in the IVD space [3]. The DDD clinical manifestations are well documented: these are BP of mechanical origin associated with axial load (getting worse with physical activity, moving heavy objects, flexion, and improving at rest) and/or with spinal stenosis, radiculopathy, and less often with myelopathy. DDD is one of the causes of chronic segmental instability and early disability in the working age patients. Studies have shown that the IVD degeneration is a multifaceted process, involving apoptosis, inflammation, ageing, and biomechanical dysfunction [4]. Recently, considerable attention has been paid to studying the effects of inflammatory cytokines on the DDD development, as well as to the imbalance between the proinflammatory and anti-inflammatory cytokines [5].

It is shown, that inflammatory pattern triggers the catabolic processes in the cartilage matrix of the compromized functional spinal unit, together with further degeneration of extracellular matrix and dehydratation of nucleus pulposus (NP) and annulus fibrosus (AF) [5, 6]. The loss of the disc structural integrity and the AF microcracks cause the prolapse of the NP content into the AF tissue and outwards with the formation of protrusion, extrusion, and sequestration. The role of TNF $\alpha, I L 1 \beta$, overexpression of IL6, and CD16 monocytes in the development and progression of degenerative changes is being discussed in literature. It is important to mention that the cytokine expression may be correlated with the IVD degeneration severity. The role of IL6 in the disc degeneration and herniation was studied by many researchers [7]. The hypothesis about the IL6 involvement in the human IVD degeneration was confirmed by the fact that the abundance of the catabolic gene transcript increased, and the expression of genes encoding proteoglycans was suppressed with the increase in the IL6 expression [8]. Studying the role of IL17 in the DDD-associated inflammatory cascade showed that the exposure of human NP cells to IL17 and TNF $\alpha$ contributed to the increased release of IL6 in vitro and the increased expression of intercellular adhesion molecules (ICAM-1) on the surface of cells in NP and AF [9]. The association between pain intensity, IVD herniation, and inflammatory response was defined. It was suggested to treat the listed above biomarkers as the potential markers of the disease onset, severity, and progression.

The possibility of using the analysis of serum inflammatory biomarkers for identification of degeneration and inflammation of the IVD tissues in patients with DDD was demonstrated [7, 10]. Molecular patterns of degeneration and inflammation in the disc tissued were assessed in order to develop the approaches to the reparative therapy of DDD [3]. IL1 $\beta, T N F \alpha$, and VEGF were verified by immunohistochemistry in individuals of various ages having no symptoms of BP [11]; the expression of these markers in the disc tissues showed almost no differences between the groups of young and elderly individuals having no symptoms of the disease. Accordingly, measuring the cytokine levels in the damaged disc is an important challenge in terms of searching for the pathogenetically substantiated antiinflammatory and reparative therapy. Recently, the role of the vascular endothelial growth factor (VEGF, VFA) in the disc tissue vascularization (the disc is normally avascular) at all stages of the IVD degeneration was shown. The VEGF activity is realized via regulation of the soluble vascular endothelial growth factor receptor 1 expression [12].

When studying the pattern of the hernia resorption in patients with DDD (confirmed by MRI), Japanese researchers assessed the interaction sequence TNF $\alpha$-VEGF-MMP (matrix metalloproteinases MMP-3 and MMP-7 involved in degradation of the extracellular matrix proteins, aggrecan and collagen) and found that the expression of mRNA and VEGF protein increased in the situation of the contact between macrophages and human disc tissues in vitro, and positively correlated with the TNF $\alpha$ expression levels [13]. Thus, it was shown that neovascularization promoted the reverse development of intervertebral hernias. The process of the capillary ingrowth into the IVD tissue was confirmed by magnetic resonance imaging (MRI) with the use of gadolinium-based contrast agents, and could serve as an additional determinant of the extrusion resorption [14].

The relationship between the markers of aseptic inflammation and IVD reparation in the disk tissues, and the abundance of those in peripheral blood of young patients with advanced grade DDD have not been fully defined. Various data are available on the preponderant role in altering the IVD immune homeostasis, played by one or another cytokine. Studying the cytokine profile (together with the features of the functional spinal unit lesion) would make it possible to define the immune phenotypes of patients in order to develop the biological targets for therapy and prognosis of the disease. The study was aimed to define the profiles of the key biomarkers of inflammatory damage (TNF $\alpha$, IL6, IL17, IL1 $\beta$ ) and angiogenesis (isoforms of the vascular endothelial growth factor A, VEGF121, VEGF165, and VEGF189) in the cartilage tissue of IVDs and white blood cells of young patients with DDD, who underwent discectomy, compared to controls.

\section{METHODS}

The study was carried out at the Department of Neurosurgery, Pirogov City Clinical Hospital № 1, and A.I. Nesterov Department of Faculty Therapy, Pirogov Russian National Research Medical University, in 2019-2021. A total of 87 young (aged 18-44 in accordance with the WHO classification, 2012) adults were enrolled (40 males and 48 females). Index group inclusion criteria: young patients (median age 37.01 years [35.54-38.49]) having BP associated with DDD, confirmed by instrumental evaluation (MRI) (Table). Exclusion criteria: history of spinal injury or spinal injury at the time of the study, tumors and infections affecting the spine and other organs, inflammatory spondyloarthropathy, surgical interventions in the previous 30 days. All individuals in the index group underwent surgery (microdiscectomy) due to the spinal disc herniation at the corresponding level in the lumbar spine. Pain intensity was measured in millimeters using the Visual Analogue Scale (VAS). The functional limitations in the lumbar spine were assessed based on the Backache Index (BAI) [15]. The control group was represented by healthy volunteers with no BP (20 individuals), comparable in gender and age. All patients and controls underwent MRI of the lumbar spine prior to surgery. IVD degeneration was assessed based on the reduced IVD 
Table. Demographic, clinical and instrumental characteristics of the studied groups

\begin{tabular}{|c|c|c|c|c|c|}
\hline Characteristics of patients & \multicolumn{2}{|c|}{ Index group } & \multicolumn{2}{|c|}{ Control group } & P I-II \\
\hline Number of patients & \multirow{3}{*}{\multicolumn{2}{|c|}{$\begin{array}{l}67 \\
30 \\
37\end{array}$}} & \multirow{3}{*}{\multicolumn{2}{|c|}{$\begin{array}{l}20 \\
10 \\
10\end{array}$}} & \\
\hline females & & & & & \\
\hline males & & & & & \\
\hline \multirow{2}{*}{ Average age, years } & $\mathrm{Me}$ & LQ-UQ & $\mathrm{Me}$ & LQ-UQ & \\
\hline & 37,01 & {$[35,54-38,49]$} & 34,5 & {$[29,26-39,74]$} & $<0,01$ \\
\hline $\begin{array}{l}\text { Pfirrmann degeneration grade at the level of } \\
\text { L1-L5 (mean value) }\end{array}$ & 2,62 & {$[2,4-3,0]$} & 1,2 & {$[1,1-1,8]$} & $<0,01$ \\
\hline \multirow{2}{*}{$\begin{array}{l}\text { Pfirrmann degeneration grade at the level } \\
\text { of operated IVD (mean value) }\end{array}$} & M & $\sigma$ & M & $\sigma$ & \\
\hline & 4,26 & $\pm 0,59$ & 2,15 & $\pm 1,18$ & $<0,01$ \\
\hline \multirow[b]{2}{*}{$\begin{array}{l}\text { Number of patients with herniated IVDs } \\
\text { at the level of L4-L5 } \\
\text { at the level of L5-S1 }\end{array}$} & \multicolumn{2}{|c|}{ Abs. (\%) } & \multicolumn{2}{|c|}{ Abs. (\%) } & \\
\hline & \multicolumn{2}{|c|}{$\begin{array}{l}24(43) \\
36(64)\end{array}$} & \multicolumn{2}{|c|}{$\begin{array}{c}1(5) \\
0\end{array}$} & $<0,01$ \\
\hline $\begin{array}{l}\text { Number of patients with Modic changes (total) } \\
\text { Modic } 1 \\
\text { Modic } 2 \\
\text { Modic } 3\end{array}$ & $\begin{array}{l}47(70) \\
21(45) \\
26(55) \\
0\end{array}$ & & $\begin{array}{l}1(5) \\
0 \\
1(5) \\
0\end{array}$ & & $\begin{array}{l}<0,01 \\
<0,01 \\
<0,01\end{array}$ \\
\hline \multicolumn{6}{|c|}{ Index group } \\
\hline Characteristics of patients & $\mathrm{Me}$ & \multicolumn{4}{|c|}{ LQ-UQ } \\
\hline Disease duration, years & 5 & \multicolumn{4}{|c|}{$[2,0-10,0]$} \\
\hline Duration of the last painful episode, weeks & 6 & \multicolumn{4}{|c|}{$[3,0-12,0]$} \\
\hline Pain intensity (VAS, mm) & 68 & \multicolumn{4}{|c|}{$[48,0-88,0]$} \\
\hline \multirow{2}{*}{$\begin{array}{l}\text { Variant of pain syndrome } \\
\text { acute } \\
\text { chronic }\end{array}$} & Abs. & \multicolumn{4}{|c|}{$\%$} \\
\hline & $\begin{array}{l}12 \\
55\end{array}$ & \multicolumn{4}{|c|}{$\begin{array}{l}18 \\
82 \\
\end{array}$} \\
\hline $\begin{array}{l}\text { Functional impairment severity (Backache Index } \\
\text { (BAI)) } \\
\text { mild } \\
\text { moderate } \\
\text { severe }\end{array}$ & $\begin{array}{l}11 \\
16 \\
40\end{array}$ & \multicolumn{4}{|c|}{$\begin{array}{l}18 \\
24 \\
58\end{array}$} \\
\hline
\end{tabular}

signal intensity, disc space narrowing, structural changes in the disk, and blurring between the nucleus pulposus (NP) and the annulus fibrosus (AF). IVD degeneration was graded in accordance with the C.W. Pfirmann grading system (2001) (grades 1-5). Grades 3, 4, 5 were treated as irreversible damage to the disc, and grades 4, 5 were interpreted as severe DDD.

The fragments of degenerative IVDs were obtained during discectomy. Microparticles of IVD smaller than $1 \mathrm{~mm}^{3}$ were immediately immersed in the IntactRNA stabilization solution (non-toxic aqueous fixative solution for rapid stabilization of cellular RNA in tissues and cell cultures, preserving the cell integrity), and the disc tissue samples were assigned a barcode, identical to the barcode of the patient's blood samples. The same molecular markers were identified in blood and cartilalage tissue samples, selected in accordance with the recent data based on the review articles and technical accessibility of the laboratory diagnosis (DNA-Technology; Russia). The abundance of mRNAs of the studied genes in blood cells (white blood cells) and IVD tissue was defined by the reverse transcription-quantitative polymerase chain reaction method with the use of the reagent kits (DNA-Technology: Russia). Amplification was performed in the DTprime 4 PCR system (DNA-Technology; Russia).

Obtaining IVD tissue samples $\left(1 \mathrm{~mm}^{3}\right)$ : RNA was extracted after cutting the cartilage with surgical blade (sterile disposable surgical scalpel, manufactured by Huaiyin Medikal Instruments
Co. Ltd., China). After cutting, the fragment sized $1 \mathrm{~mm}$ was obtained, which was further grinded by the rubbing the conus of the microcentrifuge tube against the Petri dish bottom in order to obtain fine particles and molds. Then $320 \mu \mathrm{L}$ of the lysing solution from the Proba-NK kit (DNA-Technology; Russia) were added to the dish. The contents of the dish together with the crushed sample were transferred to the Axygen microcentrifuge tubes (Axygen, Inc.; USA), and then mixed using the Micro-Spin FV-2400 centrifuge/vortex (Biosan; Latvia) for $5 \mathrm{~s}$, and sedimented. Subsequently, this was left to lyse for $1 \mathrm{~h}$. After that RNA was isolated using the ProbaNK kit (DNA-Technology; Russia) in accordance with the manufacturer's guidelines. The extracted RNA in the amount of $16.5 \mu \mathrm{L}$ was immediately used for reverse transcription, which was performed at a temperature of $40{ }^{\circ} \mathrm{C}$ for $30 \mathrm{~min}$, with subsequent inactivation of reverse transcriptase at $95{ }^{\circ} \mathrm{C}$ for $5 \mathrm{~min}$. The resulting cDNA solution was either immediately used for quantitative PCR, or stored at $-20^{\circ} \mathrm{C}$. The volume of $35 \mu \mathrm{L}$ was used for amplification with the real-time registration of the results in accordance with the following program: 50 cycles $94{ }^{\circ} \mathrm{C}-10 \mathrm{~s}, 64^{\circ} \mathrm{C}-20 \mathrm{~s}, 72^{\circ} \mathrm{C}-10 \mathrm{~s}$. Fluorescence was measured during each cycle at a temperature of $64^{\circ} \mathrm{C}$.

The $4 \mathrm{ml}$ blood samples were collected into the disposable Vacutainer EDTA tubes (Becton Dickinson; USA) 24 hours before surgery with subsequent blood processing in order to extract white blood cells. To obtain the buffy coat, the Proba-Ficoll kit for extraction of lymphocytes from the whole blood was used. 


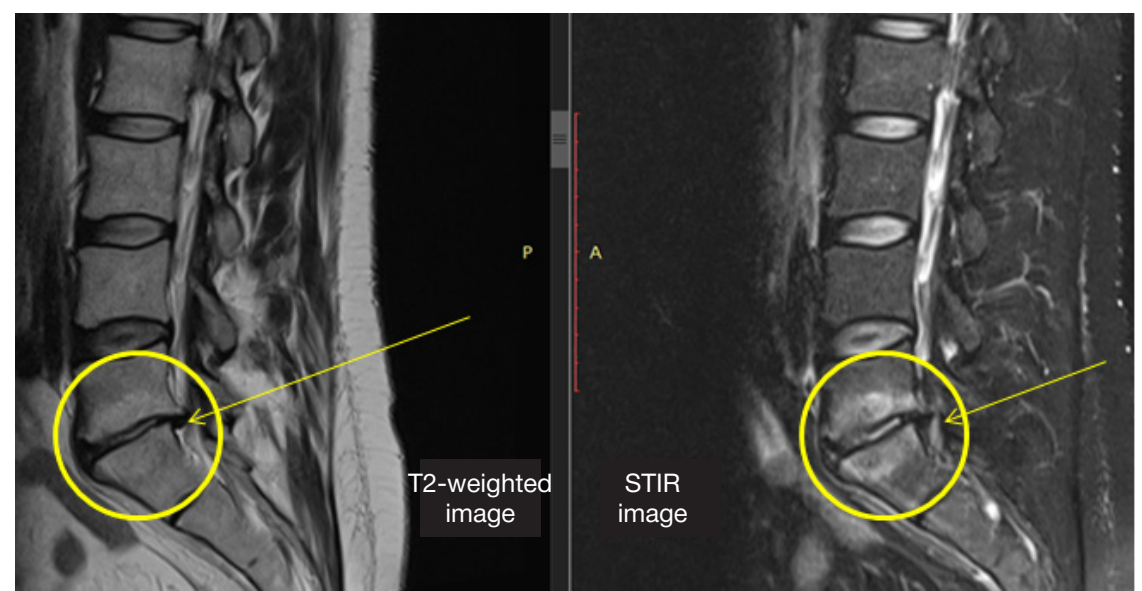

Fig. 1. Patient $K$. aged 37 with BP and Pfirrmann grade 4 DDD at the level of L5-S1, with IVD herniation (arrow) and Modic type 1 changes in vertebral bodies (yellow contour). T2-weighted and STIR images

RNA was isolated using the Proba-NK kit (DNA-Technology; Russia) in accordance with the manufacturer's guidelines. RNA extracted in the amount of $16.5 \mu \mathrm{L}$ was immediately used for reverse transcription, which was performed at a temperature of $40{ }^{\circ} \mathrm{C}$ for $30 \mathrm{~min}$, with subsequent inactivation of reverse transcriptase at $95^{\circ} \mathrm{C}$ for 5 min. The resulting cDNA solution was either immediately used for quantitative PCR, or stored at $-20{ }^{\circ} \mathrm{C}$. The volume of $35 \mu \mathrm{L}$ was used for amplification with the real-time registration of the results in accordance with the following program: 50 cycles $94^{\circ} \mathrm{C}-10 \mathrm{~s}, 64^{\circ} \mathrm{C}-20 \mathrm{~s}$, $72{ }^{\circ} \mathrm{C}-10 \mathrm{~s}$. Fluorescence was measured during each cycle at a temperature of $64^{\circ} \mathrm{C}$.

The studied genes included TNF $\alpha$, IL6, IL17, IL1 $\beta$, and isoforms of vascular endothelial growth factor A (VEGF121, VEGF165, VEGF189). Normalization genes were represented by $\beta 2$-microglobulin (B2m), and $\beta$-glucuronidase (GUSB). Normalization values for each gene mRNA were calculated by the $\triangle \triangle \mathrm{Ct}$ method [16]. The expression levels of the gene mRNAs were expressed in arbitrary units in relation to normalization genes (B2m, GUSB), which had the relatively stable expression levels.

\section{Statistical analysis}

The nonparametric method (Mann-Whitney $U$ test) was used to assess the statistical significance of the differences obtained. Quantitative indicators were tested for normality using the Shapiro-Wilk test. Qualitative indicators were compared using the chi-squared test and the two-tailed Fisher's test for small samples. The differences between groups were considered significant when $p<0.01$ and $p<0.05$. Data analysis was performed using the Statistica v 8.0, SPSS v.10, and Graph Pad Prism software.

\section{RESULTS}

\section{Clinical and instrumental characteristics of patients}

Clinical characteristics of the young patients with BP are presented in Table. The average pain intensity value corresponded to $68 \mathrm{~mm}$ [48.0-88.0]. Acute pain (lasting for a maximum of 12 weeks) was found in $18 \%$ of patients, and $82 \%$ of patients had chronic pain. The median disease

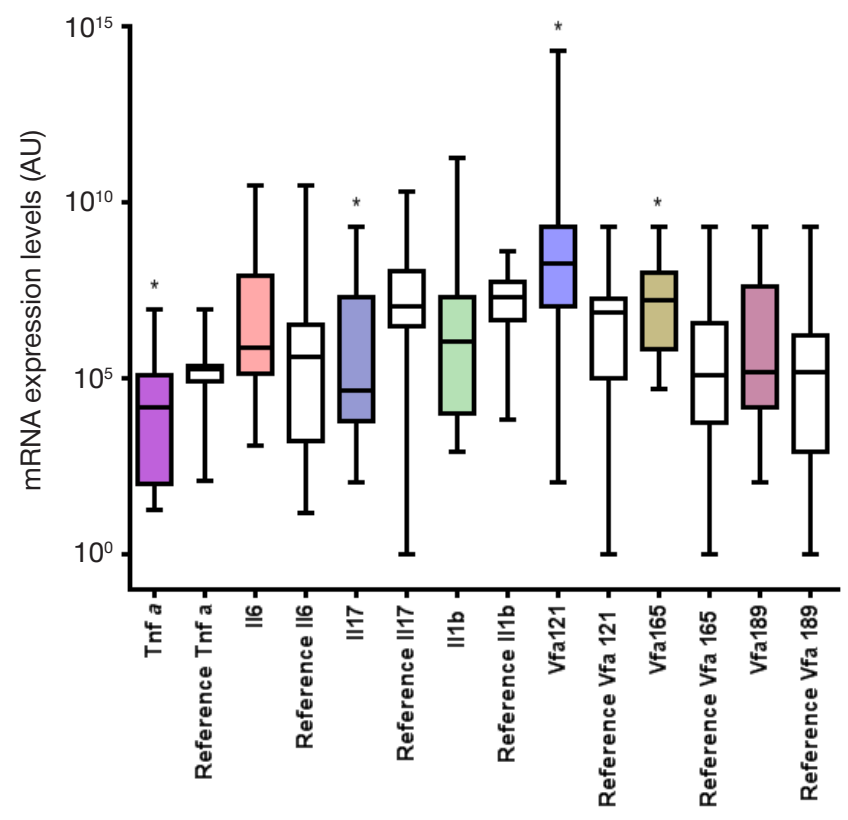

Genes

Fig. 2. Expression levels of mRNAs of the studied genes in relation to normalization genes (B2m, GUSB) in the IVD tissues of the index group patients and controls $\left({ }^{*}-p<0.01\right)$ 


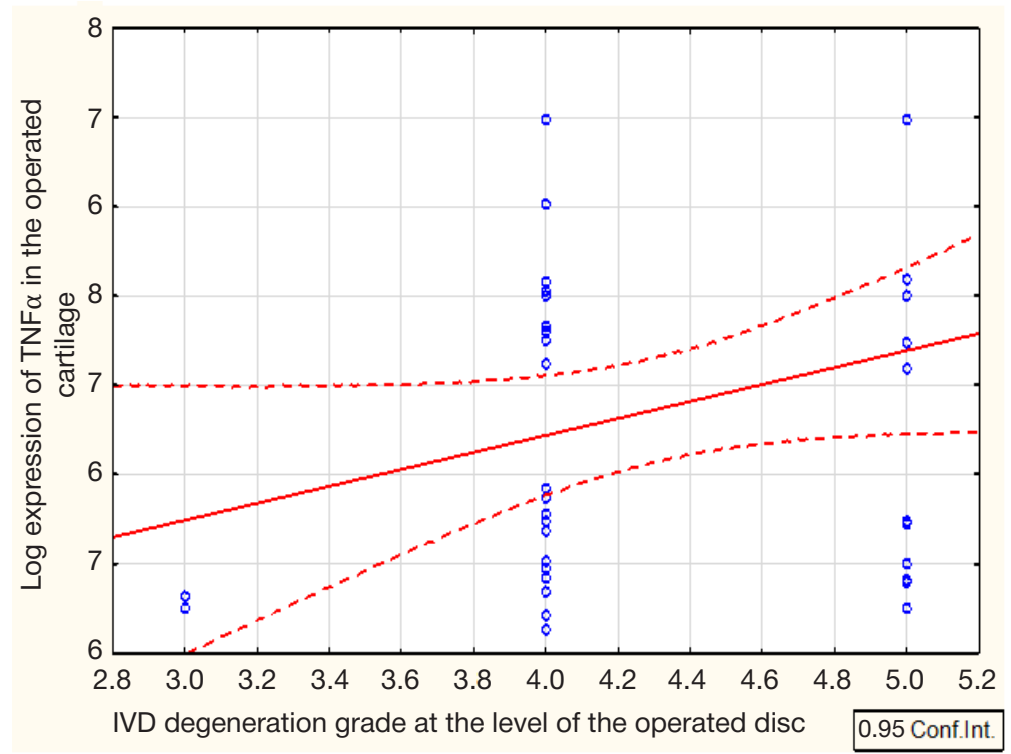

Fig. 3. Correlation between the TNF $\alpha$ mRNA expression levels in the IVD tissues and the Pfirrmann degeneration grades in the index group patients

duration in the latter was 5 years [2.0-10.0]. Based on BAI values, $82 \%$ of patients had moderate and severe functional impairment. The lumbar spine MRI showed the significant disc space narrowing, blurring between NP and AF, and reduced NP signal intensity. At the level of the operated disc, the IVD degeneration grade corresponded to grades 4 and 5 of the Pfirrmann grading system in $66 \%$ and $33 \%$ of the index group patients, respectively. Herniation was localized at the levels of L4-L5, L5-S1 at a ratio of 36 and 64\%, respectively. In 70\% of patients, MRI at the level of the operated disc revealed the altered intensity of the bone marrow MR signal on the T2-weighted and STIR (short tau inversion recovery) images, which indicated Modic type 1 changes, the bone marrow edema (45\% of patients) (Fig. 1), and Modic type 2 changes, the fatty degeneration (55\%), in almost equal proportions. In the control group, Modic changes were found in only one patient (5\%) out of 20 , and these changes were also associated with severe DDD and asymptomatic IVD herniation. MRI revealed the combination of IVD herniation with erosions of the adjacent vertebral body endplates and Modic changes in 37 index group patients (53.6\%). Such a "triple combination" was associated with longer BP duration (years), morning pain, and persistent chronic pain with no "lucid intervals" $(p<0.05)$ compared to patients with no erosions of the vertebral body endplates and/ or Modic changes. The index group patients and the controls showed significant differences in the average Pfirrmann DDD grades and the prevalence of Modic changes (4.4 and 2.8 for DDD grades, 70 and $5 \%$ for Modic changes; $p<0.01$ ). The findings confirm the correlation of Modic changes with IVD herniation and severe DDD.

\section{Abundance of mRNAs of cytokines and vascular endothelial growth factor isoforms in IVD tissues}

Of all mRNAs of the studied genes, encoding cytokines and vascular endothelial growth factor isoforms, the TNF $\alpha, \mathrm{IL} 17$, VEGF121, and VEGF165 expression in the cartilage tissue was significantly elevated $(p<0.01)$ compared to the control group (Fig. 2). Juxtaposing the mRNA expression levels of all genes, studied in the index group patients, with the IVD degeneration Pfirrmann grades revealed a positive correlation between the expression of TNF $\alpha$ and the IVD degeneration grades $(r=0.301$; $p<0.05$ ) (Fig. 3). Despite the fact that the expression of the IL1 $\beta$ mRNA showed no significant differences with the control group, the abundance of this gene in the disc tissue correlated with the disc degeneration severity $(r=0.37 ; p<0.05)$ (Fig. 4).

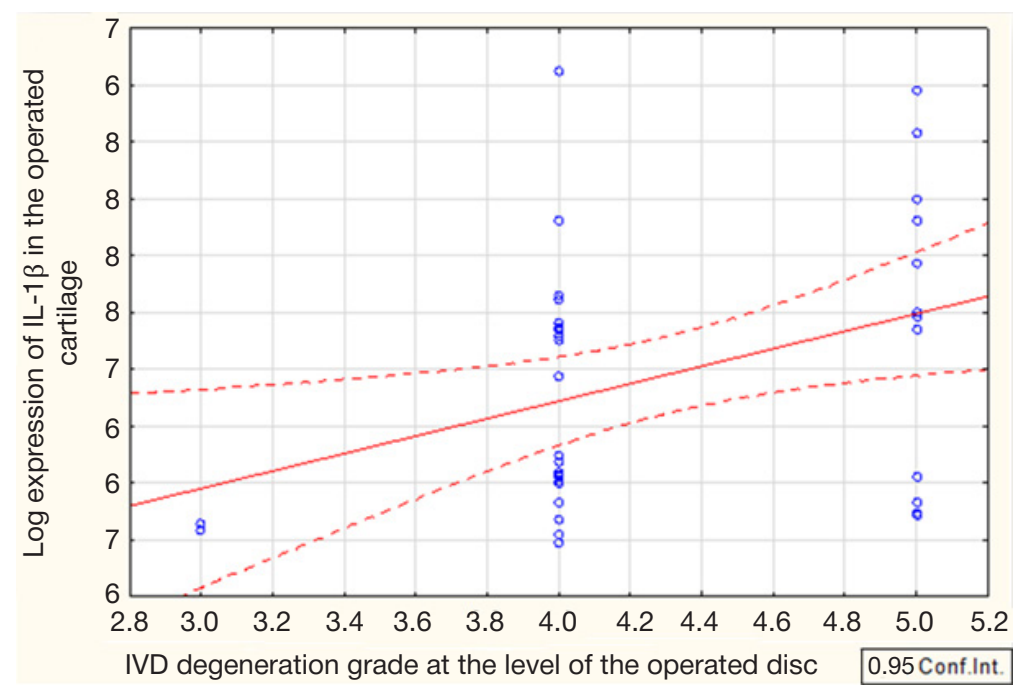

Fig. 4. Correlation between the IL1 $\beta$ mRNA expression levels in the IVD tissues and the Pfirrmann degeneration grades in the index group patients 


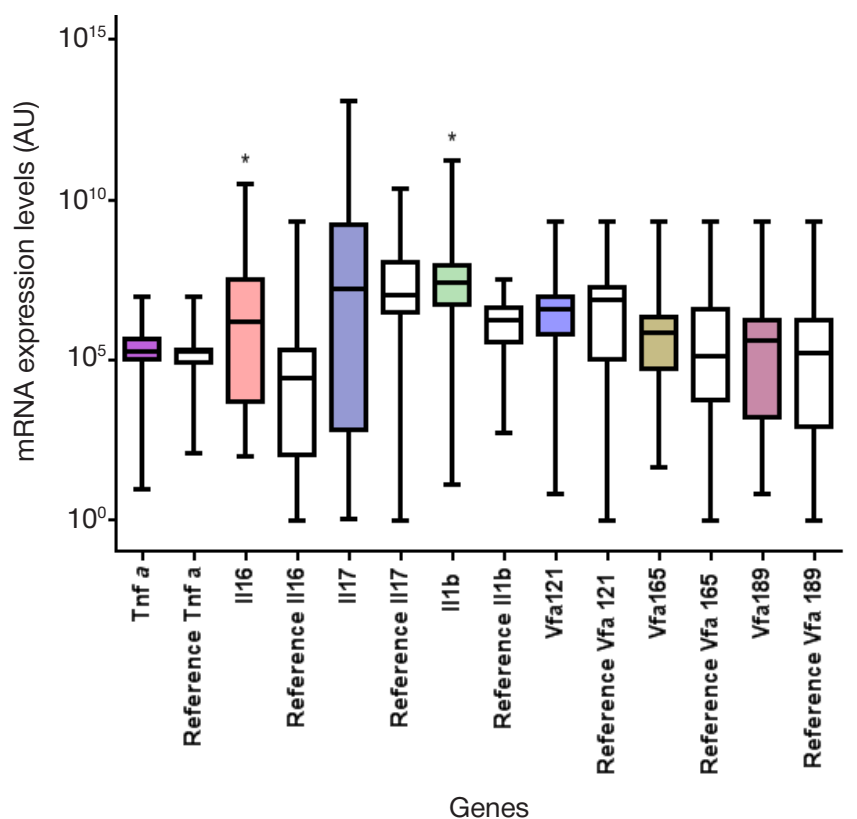

Fig. 5. Expression levels of mRNAs of the studied genes in relation to normalization genes (B2m, GUSB) in the white blood cells of the index group patients and controls $(p<0.01)$

From the perspective of the IVD matter disorganization progression, it was interesting to assess the cartilage vascularization markers in IVDs with grade 4 or 5 degeneration. The significant negative correlation between the levels of VEGF121 and the IVD degeneration grades $(r=-0.85 ; p<0.001)$ was identified for vascular endothelial growth factors, which could indicate the decreased angiogenesis intensity in the discs of patients with the advanced stage DDD.

\section{Analysis of gene abundance in blood cells}

Further analysis was aimed to identify mRNAs of cytokines and growth factors in peripheral white blood cells. Our study revealed the significantly increased abundance of the genes, encoding interleukins IL1 $\beta$, IL6 ( $p<0.01)$ (Fig. 5). Analysis of the relationship between the expression of the IL6 cytokine mRNA in peripheral blood and the IVD degeneration grade showed the dicrease in the cytokine levels in the discs with the advanced IVD Pfirrmann degeneration grades $(r=-0.347 ; p<0.05)$, which was indicative of the cytokine significant contribution to degeneration at earlier stages.

Taking into account the high prevalence of Modic changes in the vertebral bodies (70\%) of the index group patients, we assessed the relationship between the cytokine expression levels and the presence of Modic changes. A significant negative correlation between the IL6 levels in blood cells and Modic type 1 and 2 changes was revealed $(r=-0.31 ; p<0.05)$, which was indicative of the elevated cytokine expression at the stage of inflammatory bone marrow edema compared to the stage of fatty transformation within the adjacent vertebral bodies. Individuals with a more severe lesion in their functional spinal units, the triple combination (herniation + erosions of the vertebral body endplates + Modic) $(r=0.401 ; p<0.05)$, had a higher expression of IL17 in their peripheral blood compared to individuals having herniation only. Regardless of the low abundance of angiogenic biomarkers in blood of patients with $\mathrm{BP}$, we decided to see whether the vascular endothelial growth factor (isoforms 121, 165, 189) expression levels changed depending on the IVD degeneration grades: significant negative correlations were obtained for all three isoforms $(r=-0.44$; -0.33 , and -0.45 , respectively; $p<0.05$ ).

\section{DISCUSSION}

Studying the BP pathophysiology in young patients confirmed the involvement of immune and inflammatory mechanisms in disc degeneration. High expression of TNF $\alpha$ and TNF $\alpha$ receptors, especially in the AF tissue, in patients with DDD, was also reported by other authors $[17,18]$. This specific cytokine was described in experiments as an apparent inducer of matrix degradation, especially at the early stages, compared to other mediators [19]. The coupled expression of TNF $\alpha$ and IL17, identified during our study, was found in two studies, conducted by Chinese researchers, and confirmed by the effects of etanercept (inhibitor of TNF $\alpha$ receptor), which was capable of quenching the entire inflammatory cascade in the disc NP tissue [20, 21]. Pathogenetic relationships between the immune inflammation and the disc vascularization, observed during our study, were shown in the overseas human and animal studies [22, 23].

Association of the elevated IL6 gene expression in peripheral blood with Modic changes, and specifically with the inflammatory bone marrow edema grade, was also shown within the framework of the study, performed by Chinese researchers: the expression of IL6 was significantly increased in elderly patients with DDD and Modic type 1 changes compared to patients with Modic type 2 changes [24]. The assessment of changes confirmed the fact of the reactive aseptic spondylitis in patients with severe DDD. Detection of the elevated IL17 expression in idividuals with the triple combination of lesions in their functional spinal units suggests the existence of the adverse clinical and instrumental phenotype of BP with the immune marker at the systemic level.

It is known that, in accordance with the Pfirrmann grading system, grade 5 of the IVD degeneration is characterized by the dramatically decreased IVD height, hypointense and nonhomogeneous signal from NP, which corresponds to severe, almost total dehydration of NR together with the extracellular matrix disintegration, replacement of the disc central space with type I collagen, and blurring between NP and AF [25]. When distinguishing between the natural age-related disc degeneration process and the abnormal disc degeneration, we wish to emphasize the key role of inflammatory markers in the second scenario, being particularly evident and manifesting 
as severe degeneration in young adults [26]. By the age of 4 , blood vessels and capillaries of the disc vanish, and the disc becomes a completely avascular structure [27]. As the "low-immune" inflammation develops in the IVD tissues, neovascularization becomes the way of the immunocompetent cells delivery from the systemic blood flow to the cartilage tissue with subsequent activation of catabolic pathways [28] and resorption of the tissue fragment that has fallen out of AF. The vascular endothelial growth factor A (VEGF) is one of the major regulators of angiogenesis. VEGF plays an important role in physiological and pathological neovascularization [29]. The VEGF expression is promoted by the activity of chondrocytes, which form clusters within the NP. In grade 5 DDD, the disc might no longer have the NP along with the rest of the NP cellular content, which is likely to disrupt the angiogenesis stimulation pathway in this settings. These data are consistent with the study, which has shown that the VEGF angiogenic factor expression levels in IVD samples with mild degenerative changes are significantly higher compared to advanced degeneration grades [12]. Taking into account the low reparative capacity of the disc with grade 5 degenerative changes, the use of therapeutic bioengineering, involving the application of tissue engineering and 3D IVD scaffold fabrication with subsequent cellular therapy, is the most promising.

\section{References}

1. Zwierzchowska A, Tuz J. Evaluation of the impact of sagittal spinal curvatures on musculoskeletal disorders in young people. Med Pr. 2018; 69 (1): 29-36. DOI: 10.13075/mp.5893.00558.

2. Fujii K, Yamazaki M, Kang JD, Risbud MV, Cho SK, Qureshi SA et al. Discogenic Back Pain: Literature Review of Definition, Diagnosis, and Treatment JBMR Plus. 2019; 3 (5): e10180. DOI: 10.1002/jbm4.10180.

3. Anitua E, Padilla S. Biologic therapies to enhance intervertebral disc repair. RegenMed. 2018; 13 (1): 55-72. DOI: 10.2217/rme2017-0111

4. Hu S, Fu Y, Yan B, Shen Z, Lan T. Analysis of key genes and pathways associated with the pathogenesis of intervertebral disc degeneration. J Orthop Surg Res. 2020; 15 (1): 371. DOl: 10.1186/s13018-020-01902-4.

5. Li Y, Liu J, Liu Z, Duan D. Inflammation in low back pain may be detected from the peripheral blood: suggestions for biomarker. Biosci Rep. 2016; 36 (4): e00361. DOI: 10.1042/BSR20160187.

6. Hodgkinson T, Shen B, Diwan A, Hoyland JA, Richardson SM. Therapeutic potential of growth differentiation factors in the treatment of degenerative disc diseases. Spine. 2019; 2 (1): e1045. DOI: 10.1002/jsp2.1045.

7. Kraychete DC, Sakata RK, Issy AM, Bacellar O, Santos-Jesus R, Carvalho EM. Serum cytokine levels in patients with chronic low back pain due to herniated disc: analytical cross-sectional study. Sao Paulo Med J. 2010; 128 (5): 259-62. DOI: 10.1590/s151631802010000500003

8. Studer RK, Vo N, Sowa G, Ondeck C, Kang J. Human nucleus pulposus cells react to IL6: independent actions and amplification of response to IL1 and TNF $\alpha$. Spine. 36: 593-9. DOI: 10.1097/ BRS.0b013e3181da38d5

9. Gabr MA, Jing L, Helbling AR, Sinclair SM, Allen KD, Shamji MF, et al. Interleukin-17 synergizes with IFN $\gamma$ or TNF $\alpha$ to promote inflammatory mediator release and intercellular adhesion molecule-1 (ICAM-1) expression in human intervertebral disc cells. J Orthop Res. 2011; 29 (1): 1-7. DOI: 10.1002/jor.21206.

10. Rodrigues LMR, Oliveira LZ, Silva MBRD, Accardo CM, Giglio ABD, Pinhal MADS. Inflammatory biomarkers in sera of patients with intervertebral disc degeneration. Einstein (Sao Paulo). 2019; 17 (4): eAO4637. DOI: 10.31744/einstein_journal/2019AO4637.

\section{CONCLUSIONS}

The study sheds light on the range of activated genes, which express cytokines, and shows the inflammatory profiles of those in IVD tissues and peripheral blood depending on the DDD severity and the area of the functional spinal unit lesion. The abundance of mRNAs of the studied cytokines and vascular endothelial growth factor isoforms in the IVD tissues (TNF $\alpha$, IL17, VEGF121, VEGF165) was higher in individuals with BP and DDD. The vascular endothelial growth factor expression levels, reflecting the possible processes of neovascularization, dramatically decreased in patients with the terminal grade DDD, both in the IVD tissues and in peripheral blood. However, the levels of TNF $\alpha$ and IL1 $\beta$ cytokines in the cartilage tissue positively correlated with the severity of the IVD degeneration, which was in line with the concept of immune inflammation, associated with DDD. The IL6 gene expression levels in white blood cells turned out to be increased in patients with Modic changes and were to a greater extent associated with inflammatory bone marrow edema in adjacent vertebral bodies at the level of the compromized segments, and the levels of IL17 turned out to be increased in patients with a combination of herniation, erosions of the adjacent vertebral body endplates, and Modic changes. The findings would help to identify the molecular targets and new directions for the anti-inflammatory and reparative therapy of DDD.

11. Baptista JS, Traynelis VC, Liberti EA, Fontes RBV. Expression of degenerative markers in intervertebral discs of young and elderly asymptomatic individuals. PLoS One. 2020; 15 (1): e0228155. DOI: 10.1371/journal.pone.0228155.

12. Capossela S, Bertolo A, Gunasekera K, Pötzel T, Baur M, Stoyanov JV. VEGF vascularization pathway in human intervertebral disc does not change during the disc degeneration process. BMC Res Notes. 2018; 11: 333 DOl: 10.1186/s13104-018-3441-3.

13. Haro $H$, Kato $T$, Komori $H$, Osada M, Shinomiya K. Vascular endothelial growth factor (VEGF)-induced angiogenesis in herniated disc resorption. J Orthop Res. 2002; 20 (3): 409-15. DOI: 10.1016/S0736-0266(01)00150-4

14. Autio RA, Karppinen J, Niinimäki J, Ojala R, Kurunlahti M, Haapea M, et al. Determinants of spontaneous resorption of intervertebral disc herniations. Spine. 2006; 31 (11): 1247-52. DOI: 10.1097/01. brs.0000217681.83524.4a.

15. Longo UG, Loppini M, Denaro L, Maffulli N, Denaro V. Rating scales for low back pain. Br Med Bull. 2010; 94: 81-144. DOI: 10.1093/bmb/ldp052.

16. Farasyn A, Meeusen R. Validity of the new Backache Index (BAl) in patients with low back pain. Spine J. 2006; 6 (5): 565-71. DOI: 10.1016/j.spinee.2006.01.021.

17. Rebrikov DV, Samatov GA, Trofimov DYu. PCR v real'nom vremeni. M.: Laboratorija znanij, 2019; 216s.

18. Andrade $P$, Visser-Vandewalle $V$, Philippens $M$, Daemen MA, Steinbusch HWM, Buurman WA, et al. TNF-alpha levels correlate with postoperative pain severity in lumbar disc hernia patients: opposite clinical effects between TNF receptor 1 and 2. Pain. 2011; 152: 2645-52. DOI: 10.1016/j.pain.2011.08.012.

19. Altun I. Cytokine profile in degenerated painful intervertebral disc: variability with respect to duration of symptoms and type of disease. Spine J. 2016; 16 (7): 857-61. DOI: 10.1016/j. spinee.2016.03.019.

20. Kang R, Li H, Rickers K, Ringgaard S, Xie L, Bünger C. Intervertebral disc degenerative changes after intradiscal injection of TNF $\alpha$ in a porcine model. Eur Spine J. 2015; 24 (9): 2010-6. DOI: 10.1007/s00586-015-3926-x.

21. Wang S, Wei J, Fan $Y$, Ding $H$, Tian $H$, Zhou X, et al. Progranulin Is Positively Associated with Intervertebral Disc Degeneration 
by Interaction with IL10 and IL17 Through TNF Pathways. Inflammation. 2018; 41 (5): 1852-63. DOI: 10.1007/s10753-0180828-1.

22. Wang SS, Zhang W, Zhang YQ, Zhao Y, Liu Y, Li JK, et al. IL17A enhances ADAMTS-7 expression through regulation of TNF $\alpha$ in human nucleus pulposus cells. J Mol Histol. 2015; 46 (6): 475-83. DOI: 10.1007/s10735-015-9640-5.

23. Ohba T, Haro H, Ando T, Wako M, Suenaga F, Aso Y, et al. TNFalpha-induced NF-kappaB signaling reverses age-related declines in VEGF induction and angiogenic activity in intervertebral disc tissues. J Orthop Res. 2009; 27 (2): 229-35. DOI: 10.1002/ jor.20727.

24. Binch AL, Cole AA, Breakwell LM, Michael AL, Chiverton N, Cross AK, et al. Expression and regulation of neurotrophic and angiogenic factors during human intervertebral disc degeneration. Arthritis Res Ther. 2014; 16 (5): 416. DOI: 10.1186/s13075-0140416-1.

25. Zhang JF, Wang GL, Zhou ZJ, Fang XQ, Chen S, Fan SW. Expression of Matrix Metalloproteinases, Tissue Inhibitors of Metalloproteinases, and Interleukins in Vertebral Cartilage Endplate. Orthop Surg. 2018; 10 (4): 306-11. DOl: 10.1111/os.12409.

26. Oh $\mathrm{CH}$, Yoon $\mathrm{SH}$. Whole Spine Disc Degeneration Survey according to the Ages and Sex Using Pfirrmann Disc Degeneration Grades. Korean J Spine. 2017; 14 (4): 148-54. DOI: 10.14245/ kjs.2017.14.4.148.

27. Akyol S, Eraslan BS, Etyemez H, Tanriverdi T, Hanci M. Catabolic cytokine expressions in patients with degenerative disc disease. Turk Neurosurg. 2010; 20 (4): 492-9. DOI: 10.5137/1019-5149. JTN.3394-10.1.

28. Takeno K, Kobayashi S, Negoro K, Uchida K, Miyazaki T, Yayama $T$, et al. Physical limitations to tissue engineering of intervertebral disc cells: effect of extracellular osmotic change on glycosaminoglycan production and cell metabolism. Laboratory investigation. J Neurosurg Spine. 2007; 7 (6): 637-44. DOl: 10.3171/SPI-07/12/637.

29. Chung SA, Khan SN, Diwan AD. The molecular basis of intervertebral disk degeneration. Orthop Clin North Am. 2003; 34 (2): 209-19. DOI: 10.1016/s0030-5898(03)00026-9.

\section{Литература}

1. Zwierzchowska A, Tuz J. Evaluation of the impact of sagittal spinal curvatures on musculoskeletal disorders in young people. Med Pr. 2018; 69 (1): 29-36. DOI: 10.13075/mp.5893.00558.

2. Fujii K, Yamazaki M, Kang JD, Risbud MV, Cho SK, Qureshi SA et al. Discogenic Back Pain: Literature Review of Definition, Diagnosis, and Treatment JBMR Plus. 2019; 3 (5): e10180. DOI: 10.1002/jbm4.10180.

3. Anitua E, Padilla S. Biologic therapies to enhance intervertebral disc repair. RegenMed. 2018; 13 (1): 55-72. DOI: 10.2217/rme2017-0111.

4. Hu S, Fu Y, Yan B, Shen Z, Lan T. Analysis of key genes and pathways associated with the pathogenesis of intervertebral disc degeneration. J Orthop Surg Res. 2020; 15 (1): 371. DOI: 10.1186/s13018-020-01902-4.

5. Li Y, Liu J, Liu Z, Duan D. Inflammation in low back pain may be detected from the peripheral blood: suggestions for biomarker. Biosci Rep. 2016; 36 (4): e00361. DOI: 10.1042/BSR20160187.

6. Hodgkinson T, Shen B, Diwan A, Hoyland JA, Richardson SM. Therapeutic potential of growth differentiation factors in the treatment of degenerative disc diseases. Spine. 2019; 2 (1) e1045. DOI: 10.1002/jsp2.1045

7. Kraychete DC, Sakata RK, Issy AM, Bacellar O, Santos-Jesus R, Carvalho EM. Serum cytokine levels in patients with chronic low back pain due to herniated disc: analytical cross-sectional study. Sao Paulo Med J. 2010; 128 (5): 259-62. DOI: 10.1590/s151631802010000500003

8. Studer RK, Vo N, Sowa G, Ondeck C, Kang J. Human nucleus pulposus cells react to IL6: independent actions and amplification of response to IL1 and TNF $\alpha$. Spine. 36: 593-9. DOI: 10.1097/ BRS.0b013e3181da38d5

9. Gabr MA, Jing L, Helbling AR, Sinclair SM, Allen KD, Shamji MF, et al. Interleukin-17 synergizes with IFN $\gamma$ or TNF $\alpha$ to promote inflammatory mediator release and intercellular adhesion molecule-1 (ICAM-1) expression in human intervertebral disc cells. J Orthop Res. 2011; 29 (1): 1-7. DOI: 10.1002/jor.21206.

10. Rodrigues LMR, Oliveira LZ, Silva MBRD, Accardo CM, Giglio $A B D$, Pinhal MADS. Inflammatory biomarkers in sera of patients with intervertebral disc degeneration. Einstein (Sao Paulo). 2019; 17 (4): eAO4637. DOI: 10.31744/einstein journal/2019AO4637.

11. Baptista JS, Traynelis VC, Liberti EA, Fontes RBV. Expression of degenerative markers in intervertebral discs of young and elderly asymptomatic individuals. PLoS One. 2020; 15 (1): e0228155. DOI: 10.1371/journal.pone.0228155.

12. Capossela S, Bertolo A, Gunasekera K, Pötzel T, Baur M, Stoyanov JV. VEGF vascularization pathway in human intervertebral disc does not change during the disc degeneration process. BMC Res Notes. 2018; 11: 333 DOI: 10.1186/s13104-018-3441-3.

13. Haro $H$, Kato $T$, Komori $H$, Osada M, Shinomiya K. Vascular endothelial growth factor (VEGF)-induced angiogenesis in herniated disc resorption. J Orthop Res. 2002; 20 (3): 409-15. DOI: 10.1016/S0736-0266(01)00150-4

14. Autio RA, Karppinen J, Niinimäki J, Ojala R, Kurunlahti M, Haapea M, et al. Determinants of spontaneous resorption of intervertebral disc herniations. Spine. 2006; 31 (11): 1247-52. DOI: 10.1097/01. brs.0000217681.83524.4a

15. Longo UG, Loppini M, Denaro L, Maffulli N, Denaro V. Rating scales for low back pain. Br Med Bull. 2010; 94: 81-144. DOI: 10.1093/bmb/ldp052.

16. Farasyn A, Meeusen R. Validity of the new Backache Index (BAl) in patients with low back pain. Spine J. 2006; 6 (5): 565-71. DOI: 10.1016/j.spinee.2006.01.021

17. Ребриков Д. В., Саматов Г. А., Трофимов Д. Ю. ПЦР в реальном времени. М.: Лаборатория знаний, 2019; 216 с.

18. Andrade $P$, Visser-Vandewalle V, Philippens $M$, Daemen MA, Steinbusch HWM, Buurman WA, et al. TNF-alpha levels correlate with postoperative pain severity in lumbar disc hernia patients: opposite clinical effects between TNF receptor 1 and 2. Pain. 2011; 152: 2645-52. DOI: 10.1016/j.pain.2011.08.012.

19. Altun I. Cytokine profile in degenerated painful intervertebral disc: variability with respect to duration of symptoms and type of disease. Spine J. 2016; 16 (7): 857-61. DOI: 10.1016/j. spinee.2016.03.019.

20. Kang R, Li H, Rickers K, Ringgaard S, Xie L, Bünger $C$. Intervertebral disc degenerative changes after intradiscal injection of TNF $\alpha$ in a porcine model. Eur Spine J. 2015; 24 (9): 2010-6. DOI: 10.1007/s00586-015-3926-x.

21. Wang S, Wei J, Fan Y, Ding H, Tian H, Zhou X, et al. Progranulin Is Positively Associated with Intervertebral Disc Degeneration by Interaction with IL10 and IL17 Through TNF Pathways. Inflammation. 2018; 41 (5): 1852-63. DOI: 10.1007/s10753-0180828-1.

22. Wang SS, Zhang W, Zhang YQ, Zhao Y, Liu Y, Li JK, et al. IL17A enhances ADAMTS-7 expression through regulation of TNF $\alpha$ in human nucleus pulposus cells. J Mol Histol. 2015; 46 (6): 475-83. DOI: 10.1007/s10735-015-9640-5

23. Ohba T, Haro H, Ando T, Wako M, Suenaga F, Aso Y, et al. TNFalpha-induced NF-kappaB signaling reverses age-related declines in VEGF induction and angiogenic activity in intervertebral disc tissues. J Orthop Res. 2009; 27 (2): 229-35. DOI: 10.1002/ jor.20727.

24. Binch AL, Cole AA, Breakwell LM, Michael AL, Chiverton N, Cross AK, et al. Expression and regulation of neurotrophic and angiogenic factors during human intervertebral disc degeneration. Arthritis Res Ther. 2014; 16 (5): 416. DOI: 10.1186/s13075-0140416-1.

25. Zhang JF, Wang GL, Zhou ZJ, Fang XQ, Chen S, Fan SW. Expression of Matrix Metalloproteinases, Tissue Inhibitors of Metalloproteinases, and Interleukins in Vertebral Cartilage 


\section{ORIGINAL RESEARCH I NEUROLOGY}

Endplate. Orthop Surg. 2018; 10 (4): 306-11. DOI: 10.1111/os.12409.

26. $\mathrm{Oh} \mathrm{CH}$, Yoon SH. Whole Spine Disc Degeneration Survey according to the Ages and Sex Using Pfirrmann Disc Degeneration Grades. Korean J Spine. 2017; 14 (4): 148-54. DOI: 10.14245/ kjs.2017.14.4.148.

27. Akyol S, Eraslan BS, Etyemez H, Tanriverdi T, Hanci M. Catabolic cytokine expressions in patients with degenerative disc disease. Turk Neurosurg. 2010; 20 (4): 492-9. DOI: 10.5137/1019-5149. JTN.3394-10.1.
28. Takeno K, Kobayashi S, Negoro K, Uchida K, Miyazaki T, Yayama $\mathrm{T}$, et al. Physical limitations to tissue engineering of intervertebral disc cells: effect of extracellular osmotic change on glycosaminoglycan production and cell metabolism. Laboratory investigation. J Neurosurg Spine. 2007; 7 (6): 637-44. DOl: 10.3171/SPI-07/12/637.

29. Chung SA, Khan SN, Diwan AD. The molecular basis of intervertebral disk degeneration. Orthop Clin North Am. 2003; 34 (2): 209-19. DOI: 10.1016/s0030-5898(03)00026-9. 